\title{
Effect of Organic Residues as Fertilizer on Postharvest Quality of Cherry Tomatoes
}

Patrícia Lígia Dantas de Morais ${ }^{1}$
https://orcid.org/0000-0001-9317-1164

Ana Kaline da Costa Ferreira ${ }^{1}$

https://orcid.org/0000-0001-7739-574X

Maísa de Macêdo Cruz ${ }^{1}$

https://orcid.org/0000-0003-4548-7732
Fernando Henrique Alves da Silva ${ }^{1 *}$

https://orcid.org/0000-0001-7752-1881

Maria Tereza de Albuquerque Nascimento ${ }^{1}$

https://orcid.org/0000-0001-7262-6473

Nildo da Silva Dias ${ }^{1}$

https://orcid.org/0000-0002-1276-5444

${ }^{1}$ Federal Rural University of the Semi-Arid, Center for Agrarian Sciences, Mossoró, Rio Grande do Norte, Brazil.

Editor-in-Chief: Alexandre Rasi Aoki

Associate Editor: Alexandre Rasi Aoki

Received: 2020.02.08; Accepted: 2021.03.26.

*Correspondence: fernandosilvasr@hotmail.com; Tel: +55 84999468872 (F.H.A.S.).

\section{HIGHLIGHTS}

- $\mathrm{CO} 5$ increased the weight and $\mathrm{pH}$ of the fruit, with a decrease in the titratable acidity.

- Residues positively influence the nutrients $\mathrm{K}, \mathrm{Ca}, \mathrm{Cu}$ and $\mathrm{Mn}$ in cherry tomato fruits.

\begin{abstract}
Composting of domestic residues to replace cattle manure was evaluated as a fertilization option for the cherry tomato crop. Two sources of organic compounds (CO) were used to prepare compost piles: Domestic residues (DR) and bovine manure $(\mathrm{BM})$, used in 5 proportions $(\mathrm{CO} 1=15 \% \mathrm{DR}+15 \% \mathrm{BM}, \mathrm{CO} 2=$ $10 \% \mathrm{DR}+20 \% \mathrm{BM}, \mathrm{CO} 3=20 \% \mathrm{DR}+10 \% \mathrm{BM}, \mathrm{CO} 4=30 \% \mathrm{BM}$ (control) and CO5 = 30\% DR). To compost the compost piles, the organic waste (carbon source) was mixed with remnants of tree pruning (filler) from the urban cleaning service in a ratio of 1: 3. After 90 days, the compost from each matured pile was mixed with 1: 1 coconut fiber substrate and filled into $15 \mathrm{~L}$ plastic bags where the cherry tomato plants were grown. The experiment was conducted in a greenhouse using the experimental design of randomized blocks with 5 treatments and 5 replicates ( 6 fruits per sample). The organic fertilization in the proportions of manure and food residue did not provide statistically significant differences in soluble solids, total sugars, lycopene, $\beta$ carotene and micronutrients $\mathrm{Zn}, \mathrm{Fe}, \mathrm{N}$ and $\mathrm{P}$ in cherry tomato fruits. Fertilization with $\mathrm{CO} 1$ and $\mathrm{CO} 2$ increased AT, Mn and decreased the SS / AT, K and Ca ratio. There was no nutritional deficiency of tomatoes in any of the proportions of the organic residues studied.
\end{abstract}

Keywords: Solanum lycopersicum Mill; organic fertilization; $\beta$-carotene; minerals.

\section{INTRODUCTION}

The tomato (Solanum lycopersicum Mill.) is a vegetable produced and marketed worldwide. The largest tomato producers in the world in the year of 2017 were China 59.514 .773 (t), followed by India 20.708.000 $(\mathrm{t})$ and Turkey $12.750 .000(\mathrm{t})$. Brazil occupies the tenth position with 4.230.150 (t) [1]. The main national 
growers were Goiás, São Paulo and Minas Gerais, respectively [2]. Since the introduction in the Brazilian market on 1990s, cherry tomatoes (Solanum lycopersicum var. cerasiforme) have attracted interest from growers and seed companies [3]. This species has been gaining acceptance by consumers because of the excellent flavour, attractive colour, high lycopene content and prices considered affordable, stimulating its production and commercialization [4-5].

For the production it is used the conventional or organic managements. In the conventional way, prevails the use of chemical fertilizers of high solubility, which are degrading agents of organic matter. In organic management, low solubility fertilizers with high organic matter content are used to structure the soil microbiota. However, tomato is considered a intensive labour crop for an organic production, as it is highly susceptible to pests and diseases, requiring a considerable amount of pesticides in a conventional management. According to Luz and coauthors [6], the organic system proved to be agronomically viable, with a production cost $17.1 \%$ lower than the conventional one and profitability up to $113.6 \%$ higher.

The composition of the fruits varies according to the cultivar, climatic conditions and management. In general, tomatoes are rich in lycopene and vitamin C; still has low acidity, carbohydrate contents and energetic value, which represents to the consumer advantage from the nutritional, sensorial and functional point of view [7 -8].

Organic fertilization is essential for ecosystem equilibrium, as this management reduces the use of chemical fertilizers, reducing the intake of toxic waste to human health, contamination of soils and groundwater without the use of high technologies required by the system of conventional production. The organic compound is a clean technology used in the treatment of residues of organic solids considered as a method of sustainable use $[9,10,11]$. Some compounds are produced by the windmill method [40] it is the cheap method among the available composting systems, although there is no precise control over the operational variables of the process [41]. In this way, the search for the composition of the compound and the ideal quantity becomes necessary, since the origin of this material interferes in the quality and nutritional composition of the fruits.

In this perspective, the objective was to evaluate the quality and nutritional composition of cherry tomatoes fertilized with organic compost from domestic waste, associated with bovine manure.

\section{MATERIAL AND METHODS}

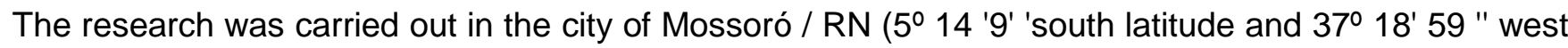
longitude, and $18 \mathrm{~m}$ ) in two stages, the first one being the reunion of the compost piles using different proportions of domestic residues and cattle manure, while in the second stage, the matured compound, for each proportion tested, was evaluated as a nutritional source in the cultivation of cherry tomato plants.

\section{Description of the Step 1}

This stage was conducted in the courtyard of the Recycling Community Association for Life (ACREVI), located in Nova Vida neighborhood, Mossoró, RN. The compost piles were constructed using three proportions of domestic residues (DR) and bovine manure $(\mathrm{BM})(\mathrm{T} 1=15 \% \mathrm{DR}+15 \% \mathrm{BM}, \mathrm{T} 2=10 \% \mathrm{DR}+$ $20 \% \mathrm{BM}$ and T3 $=20 \% \mathrm{DR}+10 \% \mathrm{BM}),(\mathrm{T} 4=30 \% \mathrm{BM}$ (control) and T5 $=30 \% \mathrm{DR})$. The organic residues (carbon source) were mixed with tree prunings (filler) in a ratio of $1: 3$. The food remains were collected in a popular restaurant and in urban dwellings, and the filling material came from pruning of the crushed trees collected by the city's urban cleaning service.

The compost piles were constructed in a conical shape with $1.60 \mathrm{~m}$ height and $2.00 \mathrm{~m}$ width, spaced and parallel to each other to facilitate the movement, the passage of materials and access. Manual composting was done every three days in the first week of composting and every ten days thereafter. The irrigations of the piles were performed daily using tap water.

During the maturation process, the cells were monitored weekly, measuring the parameters temperature, humidity and $\mathrm{pH}$. The physical and chemical properties of the compound were determined by the standard method [12], including: nitrogen $(\mathrm{N})$, phosphorus $(\mathrm{P})$, potassium $(\mathrm{K})$, calcium $(\mathrm{Ca})$, magnesium $(\mathrm{Mg})$, iron $(\mathrm{Fe})$, copper $(\mathrm{Cu})$, zinc $(\mathrm{Zn})$ and manganese $(\mathrm{Mn})$. 


\section{Description of Step 2}

After 90 days of maturation, the organic compound (CO) from each treatment of step 1 was mixed with coconut fiber substrate in a ratio of 1: 1 and packed in $15 \mathrm{~L}$ plastic vases where the cherry tomato were planted (Solanum lycopersicum Mill). The vases were drilled in the base, adding a $3-\mathrm{cm}$ layer of gravel number 1 and a $2 \mathrm{~mm}$ nylon mesh to facilitate drainage. The experiment was conducted in a greenhouse of the Department of Environmental and Technological Sciences of the Federal Rural University of the SemiArid - UFERSA (Mossoró-RN).

The organic compounds formed in the first experiment $(\mathrm{CO} 1, \mathrm{CO} 2, \mathrm{CO} 3, \mathrm{CO} 4$ and $\mathrm{CO} 5)$ were used individually to form the second experiment. The experimental design adopted was randomized blocks, with five treatments and five repetitions, resulting in 25 experimental plots, with each plot represented by six plants, totalling 150 plants. Of these six plants per plot, only four were considered useful plants and the others were discarded. Spacing of $0.35 \mathrm{~cm}$ between the vessels and $1.0 \mathrm{~m}$ between the lines was used.

The tomato sowing occurred in polystyrene trays with 128 cells, where 3 to 4 seeds per cell were used, which were filled with earthworm humus. The irrigation of the seedlings occurred manually with water supply, twice a day, in the morning (7:30 a.m.) and in the late afternoon (4:30 p.m.). The thinning was performed 10 days after sowing leaving one seedling per cell. Transplanting was performed when the plants had 4 leaves.

The automatic drip irrigation system was used, consisting of a timer to control the irrigation time programmed for two daily applications (morning - 7:30 a.m. and 4:30 p.m.). The drippers were of the selfcompensating type with flow of $2 \mathrm{~L} \mathrm{~h}-1$, where a connection with three hoses with emitting stem was installed, distributed to 3 plants.

When they reached height of $60 \mathrm{~cm}$, the plants were tutored on a single stem to avoid the contact of the branches, flowers and fruits with the soil and the possible breakage of the plants. The tutoring was done with the use of a wire, which was fixed to two wires.

After reaching full maturity, six fruits were collected per block and transported to the laboratory where the quality and nutritional composition of the fruits were evaluated. The analyzed variables were: fresh mass obtained using a semi-analytical balance; soluble solids determined with the homogenized juice of the six fruits, by digital refractometer according to AOAC [13]; The $\mathrm{pH}$ was determined using the $\mathrm{pH}$ meter, which was inserted into the homogenized juice; Titratable acidity by titration, using $1 \mathrm{gram}$ of the homogenized juice according to the Instituto Adolfo Lutz [14]; the content of lycopene and $\beta$-carotene were determined by spectrophotometry according to the method of Nagata and Yamashita [15]; soluble sugars consisted of using the antrone method proposed by Yemm and Willis [16].

The mineral contents of the fruit were determined by a humid digestion in a closed system using a microwave oven as a source of heat and concentrated nitric acid to digest the compound. The result of this process is the obtaining of a liquid extract, where it was analyzed: $\mathrm{Cu}, \mathrm{Zn}, \mathrm{Fe}, \mathrm{Mn}, \mathrm{P}, \mathrm{Ca}$, Mg, by atomic absorption spectrophotometry - EAA. Nitrogen $(\mathrm{N})$ was determined by an open system wet digestion, using the digester block [17-12]. The nutrients phosphorus $(P)$ and potassium (K), were analyzed by colorimetry and flame spectrophotometry, respectively [12].

The data were submitted to analysis of variance by the ASSISTAT 7.7 beta program [18] and the averages compared by the Scott-Knott test to the probability of $5 \%(P<0.05)$.

\section{RESULTS}

No statistically significant differences were observed between treatments for soluble solids, total sugars, lycopene and $\beta$-carotene (Tables 1 and 2). 
Table 1. Analysis of variance for quality of tomato fruits fertilized with organic compounds with different proportions of food waste and cattle manure.

\begin{tabular}{|c|c|c|c|c|c|c|c|c|c|}
\hline \multirow[b]{2}{*}{$\mathrm{FV}$} & \multirow[b]{2}{*}{$\mathrm{GL}$} & \multirow[b]{2}{*}{ Weight (g) } & \multirow[b]{2}{*}{ SS ${ }^{\circ}$} & \multirow[b]{2}{*}{ TS (\%) } & \multirow[b]{2}{*}{ AT (\%) } & \multicolumn{2}{|c|}{ Fruit quality } & \multirow[b]{2}{*}{$\begin{array}{c}\text { Lycopene } \\
\left(\mu \mathrm{g} .100 \mathrm{~mL}^{-1}\right)\end{array}$} & \multirow[b]{2}{*}{$\begin{array}{c}\beta \text {-carotene } \\
\left(\mu \mathrm{g} .100 \mathrm{~mL}^{-1}\right)\end{array}$} \\
\hline & & & & & & $\mathrm{pH}$ & SS/AT & & \\
\hline Bloc & 4 & $0.29^{n s}$ & $0.21^{\mathrm{ns}}$ & $0.68^{\text {ns }}$ & $0.019^{*}$ & $0.0027^{\mathrm{ns}}$ & $1.68^{\text {ns }}$ & $0.016^{\mathrm{ns}}$ & $0.001^{\mathrm{ns}}$ \\
\hline Treatment & 4 & $3.02^{* *}$ & $0.40^{\mathrm{ns}}$ & $0.27^{\text {ns }}$ & $0.036^{* *}$ & $0.017^{\star}$ & $4.76^{\star \star}$ & $0.016^{\text {ns }}$ & $0.0006^{\mathrm{ns}}$ \\
\hline Residue & 16 & 0.43 & 0.22 & 0.51 & 0.0059 & 0.004 & 0.67 & 0.020 & 0.0017 \\
\hline Total & 24 & & & & & & & & \\
\hline CV (\%) & & 9.45 & 9.09 & 17.57 & 11.56 & 1.46 & 10.22 & 39.59 & 25.36 \\
\hline
\end{tabular}

SS (Soluble solids); TS (total sugars); AT (titratable acidity); Ratio SS /AT. Mean at the $1 \%$ probability level $(p<0.01)$; ${ }^{*}$ at the $5 \%$ probability level $(0.01=<p<0.05)$; ns not significant $(p>=0.05) . F V=$ source of variation; $C V=$ coefficient of variation.

Table 2. Postharvest quality of tomato fruits fertilized with organic compounds with different proportions of food remains and cattle manure.

\begin{tabular}{ccccccc}
\hline Treatments & Weight $(\mathrm{g})$ & $\mathrm{SS}\left({ }^{\circ}\right.$ Brix $)$ & TS $(\%)$ & AT $(\%)$ & $\mathrm{pH}$ & SS/AT \\
\hline CO1 & $6.90 \mathrm{a}$ & $5.72 \mathrm{a}$ & $4.46 \mathrm{a}$ & $0.76 \mathrm{a}$ & $4.41 \mathrm{~b}$ & $7.55 \mathrm{c}$ \\
$\mathrm{CO} 2$ & $7.36 \mathrm{a}$ & $4.96 \mathrm{a}$ & $3.92 \mathrm{a}$ & $0.74 \mathrm{a}$ & $4.47 \mathrm{~b}$ & $6.74 \mathrm{c}$ \\
$\mathrm{CO} 3$ & $5.83 \mathrm{~b}$ & $5.27 \mathrm{a}$ & $3.95 \mathrm{a}$ & $0.64 \mathrm{~b}$ & $4.53 \mathrm{~b}$ & $8.18 \mathrm{~b}$ \\
$\mathrm{CO} 4$ & $6.94 \mathrm{a}$ & $5.21 \mathrm{a}$ & $4.17 \mathrm{a}$ & $0.63 \mathrm{~b}$ & $4.55 \mathrm{a}$ & $8.24 \mathrm{~b}$ \\
CO5 & $7.96 \mathrm{a}$ & $5.13 \mathrm{a}$ & $3.91 \mathrm{a}$ & $0.55 \mathrm{~b}$ & $4.55 \mathrm{a}$ & $9.39 \mathrm{a}$ \\
\hline CV (\%) & 9.45 & 9.09 & 17.57 & 11.56 & 1.46 & 10.22
\end{tabular}

Means followed by the same letter in the column do not differ statistically from each other by the Scott-Knott test at the $5 \%$ probability. SS (Soluble solids); TS (total sugars); AT (titratable acidity); Ratio SS /AT. CO1 (15\% DR + 15\% $\mathrm{BM}) ; \mathrm{CO} 2(10 \% \mathrm{DR}+20 \% \mathrm{BM}) ; \mathrm{CO} 3(20 \% \mathrm{DR}+10 \% \mathrm{BM}) ; \mathrm{CO} 4(30 \% \mathrm{BM})$ and CO5 (30\% DR).

For the variable mass, a significant effect was observed between treatments, showing that the treatments that obtained the lowest mass was $\mathrm{CO} 3$, the other treatments did not differ statistically (Table 2).

Significant effects of treatments were observed for titratable acidity and $\mathrm{pH}$. For titratable acidity, treatments $\mathrm{CO} 1$ and $\mathrm{CO} 2$, they stood out with greater acidity. The $\mathrm{pH}$ showed an opposite behavior to the titratable acidity as expected, where the compounds CO4 and CO5, which are the controls, presented the highest values (Table 2).

For the content of soluble solids and total sugars, no statistically significant differences were observed between the different types of compounds (Tables 1 and 2). A higher SS / AT ratio was found in treatment $\mathrm{CO} 5$ and lower in treatments $\mathrm{CO} 1$ and CO2 (Table 2).

For lycopene and $\beta$-carotene, there were no significant differences between the treatments studied. (Table 1).

According to the analysis of variance (Table 3) for macro and micronutrient contents in tomato fruits grown under different organic compounds, a significant effect was observed at $5 \%$ probability level in manganese (Mn). For the concentrations of potassium (K), calcium (Ca) and copper (Cu) a significant effect was observed at $1 \%$ probability. However, the nitrogen $(\mathrm{N})$, phosphorus $(\mathrm{P})$, magnesium $(\mathrm{Mg})$, iron $(\mathrm{Fe})$ and zinc $(\mathrm{Zn})$ contents of the fruits were not influenced by the treatments. 
Table 3. Analysis of variance for nutrition in tomato fruits fertilized with organic compounds with different proportions of food remains and cattle manure.

\begin{tabular}{lcccccccccc}
\hline & & \multicolumn{10}{c}{ Frut's nutrients } \\
\cline { 2 - 10 } FV & $\mathrm{GL}$ & $\mathrm{N}$ & $\mathrm{P}$ & $\mathrm{K}$ & $\mathrm{Ca}$ & $\mathrm{Mg}$ & $\mathrm{Cu}$ & $\mathrm{Mn}$ & $\mathrm{Fe}$ & $\mathrm{Zn}$ \\
Bloc & 4 & $0.78^{\text {ns }}$ & $0.44^{\text {ns }}$ & $4.21^{\text {ns }}$ & $0.14^{\text {ns }}$ & $0.01^{\text {ns }}$ & $1.32^{\text {ns }}$ & $2.63^{\text {ns }}$ & $127.67^{\text {ns }}$ & $11.19^{\text {ns }}$ \\
Treatment & 4 & $2.14^{\text {ns }}$ & $0.46^{\text {ns }}$ & $52.04^{* *}$ & $1.36^{* *}$ & $0.05^{\text {ns }}$ & $8.40^{\text {** }}$ & $15.98^{*}$ & $179.48^{\text {ns }}$ & $23.08^{\text {ns }}$ \\
Residue & 16 & 2.04 & 0.26 & 3.97 & 0.12 & 0.02 & $0.77^{4}$ & 4.36 & 100.88 & 80.57 \\
Total & 24 & & & & & & & & & \\
\hline
\end{tabular}

CV (\%)

$\begin{array}{lllllllll}10.60 & 23.96 & 28.68 & 10.84 & 9.66 & 22.05 & 14.41 & 26.19 & 57.69\end{array}$

Mean at the $1 \%$ probability level $(p<0.01) ;{ }^{*}$ at the $5 \%$ probability level $(0.01=<p<0.05)$; ns not significant $(p>=0.05)$. $\mathrm{FV}=$ source of variation; $\mathrm{CV}=$ coefficient of variation.

According to the mean test (Table 4), the order of nutrient accumulation in the fruit is verified. The macronutrients most absorbed by tomato fruits in all treatments were nitrogen $(\mathrm{N})$ and potassium $(\mathrm{K})$.

The other macronutrients most absorbed were $\mathrm{P}, \mathrm{Ca}$ and $\mathrm{Mg}$, at different levels in the treatments (Table 4).

Table 4. Average of the macronutrients in the fruits of the tomato fertilized with organic compounds with different proportions of food remains and cattle manure.

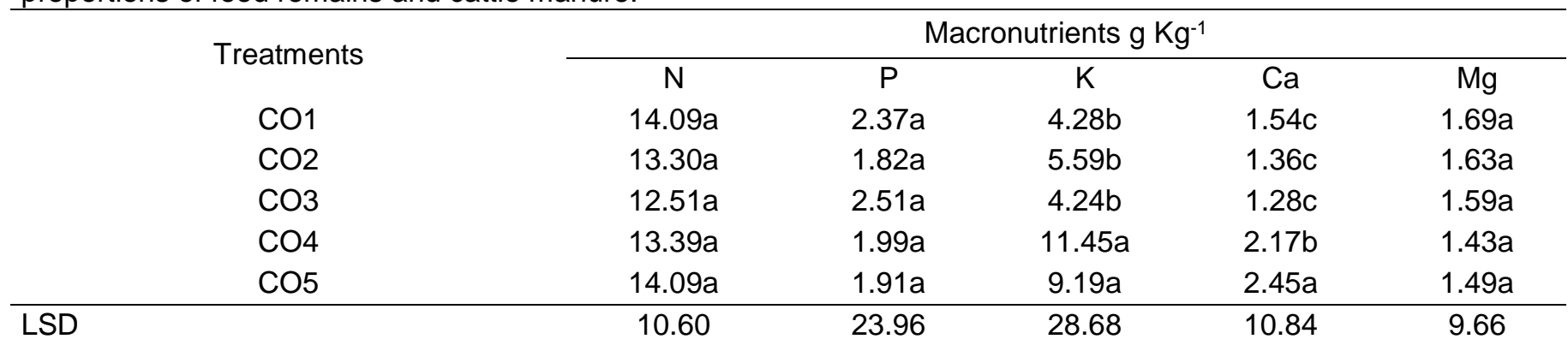

The averages followed by the same letter do not differ statistically from each other by the Scott-Knott test at the $5 \%$ probability level. CO1 (15\% DR + 15\% BM); CO2 (10\% DR + 20\% BM); CO3 (20\%DR + 10\%BM); CO4 (30\% BM) and $\operatorname{CO5}(30 \% \mathrm{DR})$.

With respect to the significant effect of the nutrient contents, it was observed that only the macronutrients contents $\mathrm{K}$ and $\mathrm{Ca}$ in the fruits were influenced by the diversity of materials used in each pile that originated the different organic compounds. It was also observed in Table 4 that the $\mathrm{CO} 4$ and $\mathrm{CO} 5$ treatments stood out for the accumulation of $\mathrm{K}$ in the fruits The lowest concentrations of $\mathrm{K}$ in the fruits occurred in the treatments CO1, CO2 and CO3, which did not differ statistically.

Similar behaviour was found in the assimilation of $\mathrm{Ca}$, where it was found higher levels in the $\mathrm{CO} 5$ treatment and followed treatment $\mathrm{CO} 4$. The treatments that did not differ statistically and showed lower contents of this nutrient were $\mathrm{CO} 1, \mathrm{CO} 2$ and $\mathrm{CO} 3$ (Table 4).

Regarding the absorption of the micronutrients evaluated in the fruits, it is verified in Table 5 that, the iron excelled in all the treatments. It was also observed (Table 6) the levels of manganese (Mn) and zinc $(\mathrm{Zn})$, with the $\mathrm{Zn}$ micronutrient not presenting a statistical difference in the treatments, since the Mn was found in greater quantity in the fruits cultivated in the $\mathrm{CO} 2$ and $\mathrm{CO} 1$ treatments. The lowest accumulation of manganese in the fruits was verified in $\mathrm{CO} 3, \mathrm{CO} 4$ and $\mathrm{CO} 5$ treatments, being statistically similar. 
Table 5. Average of micronutrients in the fruits of tomatoes fertilized with organic compounds with different proportions of food residues and cattle manure.

\begin{tabular}{ccccc}
\hline & \multicolumn{4}{c}{ Micronutrients mg Kg-1 } \\
\cline { 2 - 5 } Treatments & $\mathrm{Cu}$ & $\mathrm{Mn}$ & $\mathrm{Fe}$ & $\mathrm{Zn}$ \\
$\mathrm{nyyyy}$ CO1 & $2.25 \mathrm{c}$ & $15.82 \mathrm{a}$ & $31.73 \mathrm{a}$ & $15.15 \mathrm{a}$ \\
$\mathrm{CO} 2$ & $3.75 \mathrm{~b}$ & $16.87 \mathrm{a}$ & $37.27 \mathrm{a}$ & $15.15 \mathrm{a}$ \\
$\mathrm{CO} 3$ & $3.56 \mathrm{~b}$ & $13.72 \mathrm{~b}$ & $46.48 \mathrm{a}$ & $19.28 \mathrm{a}$ \\
$\mathrm{CO}$ & $4.64 \mathrm{a}$ & $12.55 \mathrm{~b}$ & $34.11 \mathrm{a}$ & $14.32 \mathrm{a}$ \\
& $\mathrm{CO5}$ & $13.49 \mathrm{~b}$ & $42.16 \mathrm{a}$ & $13.91 \mathrm{a}$ \\
\hline LSD & $5.73 \mathrm{a}$ & 14.41 & 26.19 & 57.67 \\
\hline
\end{tabular}

The averages followed by the same letter do not differ statistically from each other by the Scott-Knott test at the $5 \%$ probability level. CO1 (15\% DR + 15\% BM); CO2 (10\% DR + 20\% BM); CO3 (20\% DR + 10\% BM); CO4 (30\% BM) and $\operatorname{CO5}(30 \% \mathrm{DR})$.

In general, the classification of nutrient contents found in tomato fruits in this study was: $N>\mathrm{K}>$ $\mathrm{P} \cong \mathrm{Ca} \cong \mathrm{Mg}$ and $\mathrm{Fe}>\mathrm{Zn \cong Mn}>\mathrm{Cu}$, for macros and micronutrients, respectively, whose percentages of absorption is shown in Figure $1 \mathrm{~A}$. The micronutrient less absorbed by the fruits was copper $(\mathrm{Cu})$, presenting in the treatments 3,$46 ; 5.13 ; 4.29 ; 7,07$ and $7,61 \%$ in $100 \%$ of the assimilated micronutrients in $\mathrm{CO} 1, \mathrm{CO} 2$, CO3, CO4 and CO5, respectively (Figure 1B).
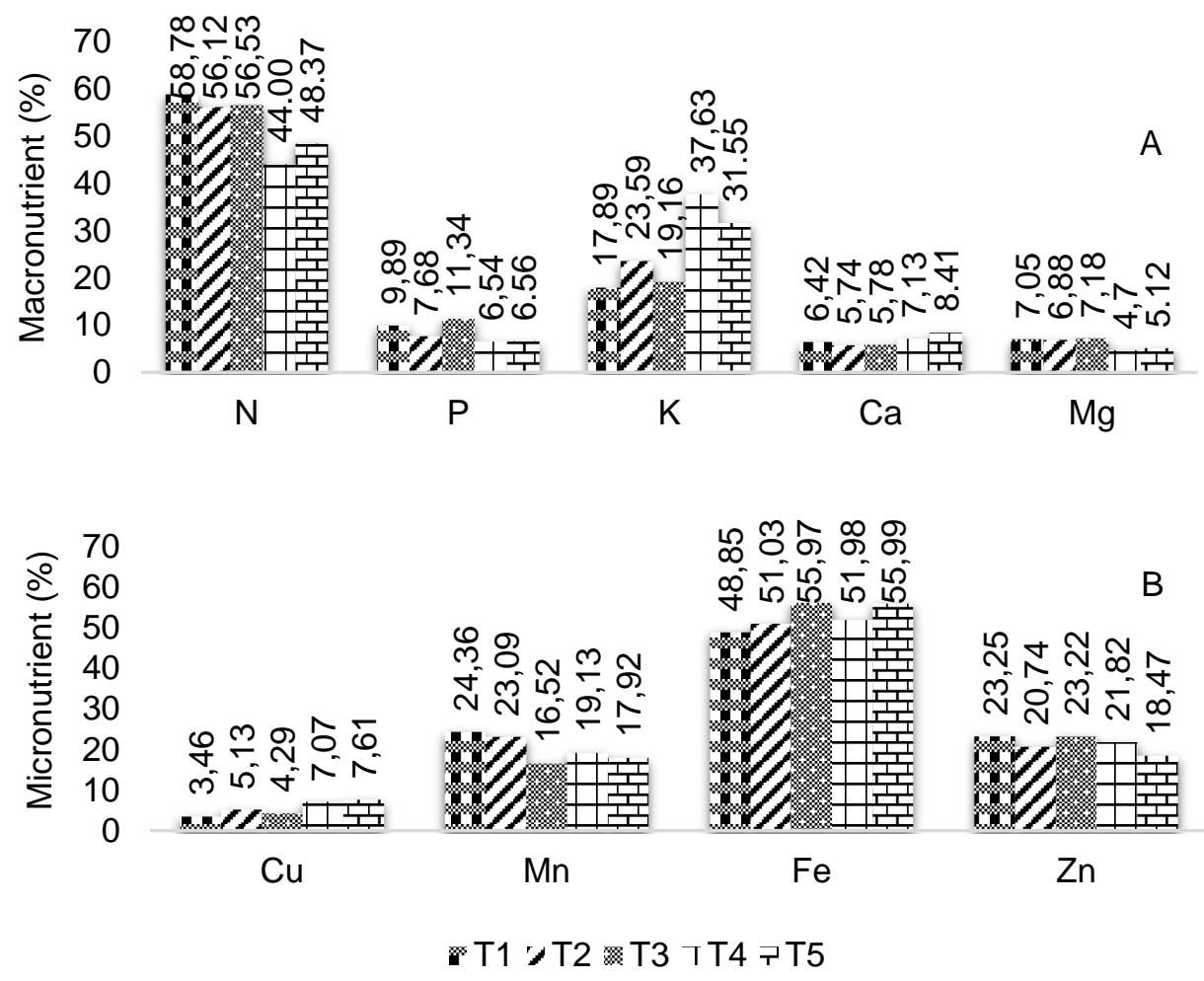

Figure 1. Percentage of macronutrients $(A)$ and micronutrients $(B)$ in tomato fruits fertilized with organic compounds with different proportions of food residues and bovine manure. CO1 (15\% DR + 15\% BM); CO2 (10\% DR + 20\% BM), $\mathrm{CO} 3(20 \% \mathrm{DR}+10 \% \mathrm{BM}), \mathrm{CO} 4(30 \% \mathrm{BM})$ and $\mathrm{CO} 5(30 \% \mathrm{DR})$.

\section{DISCUSSION}

The mass gain may be related to the diversity of the material collected for the manufacture of the compost. However, it is observed that the treatment with $\mathrm{CO}_{3}$, despite having received high concentrations of food residues and bovine manure, presented lower fruit mass, probably due to the low diversity of food remains used in the composition of this treatment, with reduced concentration of chemical element nitrogen. According to Nascimento and coauthors [19] the difference in fruit mass is due to the cultivation system used, 
the mass variable being very important from a commercial point of view, as it is the best way to indirectly demonstrate the size of the fruits

The reduction in titratable acidity is due to manure combinations and the diversity in the remains of foods, because they have low nitrogen concentrations, a fact observed in the study. The opposite result was observed by Pascale and coauthors [20] in which these authors observed an increase in titratable acidity after nitrogen fertilization source. Acidity is an important contributor to tomato flavor [21].

In this work, the $\mathrm{pH}$ was lower when compared to the conventional system [22]. The lowest $\mathrm{pH}$, particularly in the case of organic tomatoes, may be related to the higher concentration of organic acids (mainly citric and malic acid) in its cellulose fraction [23]. According to Antoniadis [24], organic materials contain macro and micronutrients, which form the organic compounds that must be mineralized to be available to plants, since nitrogen mineralization is slow and part of the mineralized nitrogen can be immobilized by microorganisms from the ground.

Soluble solids are directly influenced by the number of fruits per plant, solar irradiation, rainfall, genotype, nutritional conditions and minerals may influence the levels of some organic compounds in plants due to their influence on biochemical or physiological processes, such as translocation of photoassimilates [25-8]. Corroborating with the present study Guilherme and coauthors [26] found similar results with cherry tomatoes grown in the organic system. However, Hallmann [29] obtained results showing that the organic farming system contributes significantly to the accumulation of total sugars in tomato fruits, showing that organic farming system effect found in the research is variable, as many factors contribute to soluble solids content. The amount and types of sugars stored in tomato fruit are an important indicator of post-harvest quality, affecting the taste and overall quality of these fruits [27]. According to Teka and coauthors [28] sugar content is the main characteristic of tomato fruit, as well as high sweetness content is essential for the best taste required by the consumer.

The variation in Lycopene is related to the origin of the material and diversity used to compost the compost pile. Similar results were found by Borguini and coauthors [30] in which organic cultivation did not differ significantly between treatments.

Lycopene is the main carotenoid found in tomato fruits, representing approximately $85 \%$ of all carotenoids, this pigment increased with the increase of nitrogen, since this is the main forming element of acetyl-CoA, and this enzyme plays a role in the synthesis of carotenoid pigments and provides the conversion of $\beta$-carotene into lycopene [31], which demonstrates that the $\mathrm{CO} 3$ treatment has a lower nitrogen content. Studies have shown that fruits from organic agriculture have higher levels of lycopene $(+20 \%)$, phenolic compounds $(+24 \%)$ and flavonoids $(+21 \%)$ when compared to those from the conventional system [7]. Aguirre and coauthors [32] reported that the concentration of lycopene in the tomato depends on its chemical composition, maturation stage, genetics and interaction of the genotype with the environment in which it is inserted.

The decrease of $\beta$-carotene is possibly due to the low diversity of nutrients present in this treatment during the formation of the compost pile. The color of the tomato fruit is an important agronomic characteristic, and the $\beta$-carotene that contributes to the attractive color of the tomato is also an important antioxidant indispensable for human health [33]. Similar results of $\beta$-carotene to the present studies were observed by Nassur and coauthors [8] when they evaluated the effect of the organic compound on maintaining tomato quality.

The accumulation of nutrients is an important fact, as according to Leal [34], these are of great importance in the development, productivity and quality of the fruits. Nitrogen influences the growth, productivity and nutritional quality of tomato fruits [22]. The high value of this nutrient is associated with its structural role, being a constituent of proteins and chlorophyll molecules, in addition to other compounds of photosynthetic importance, such as nucleotides, enzymes and hormones [35]. This behavior was verified in this work, where the treatment with $\mathrm{CO} 3$ provided smaller fruits due to the lower $\mathrm{N}$ content, since the plants submitted to this treatment showed fruits with an average of $5.83 \mathrm{~g}$. Potassium $(\mathrm{K})$, according to Ernani and coauthors [36], acts on the synthesis of carbohydrates, proteins and adenosine triphosphate (ATP), as well as on the resistance to pest and disease incidence and on the permeability of plasma membranes, besides being responsible for the uniform maturation and the increase of acidity of the fruit that are characteristic important for the quality and flavour of the fruit [37].

The order of uptake of the $\mathrm{N}$ and $\mathrm{K}$ macronutrients found in tomato fruits are similar to those of Moreira [38], was observed, with the use of biofertilizer, the nutrition and development of organic tomato. However, 
the author verified higher levels for nutrients $\mathrm{P}, \mathrm{Ca}$ and $\mathrm{Mg}$, with concentrations of $5.13 ; 3.77$ and $3.63 \mathrm{~g} \mathrm{Kg}$

1 , respectively at 84 DAT.

For Guilherme and coauthors [26], the observed differences in nutrient contents are due to genetic variability as well as edaphic and climatic conditions of the cultivated areas. This variation is reflected in the taste, color, texture and odor of the fruits and in general is more pronounced in organic tomatoes, which have organoleptic characteristics more accentuated than those grown in conventional system [5-39].

This section may be also divided by subheadings. It should provide a concise and accurate description of the experimental results, their interpretation as well as the experimental conclusion that can be drawn.

\section{CONCLUSIONS}

The organic fertilization in the proportions of manure and food residue did not provide significant statistical differences in the soluble variables, total sugars, lycopene, $\beta$-carotene and micronutrients $\mathrm{Zn}, \mathrm{Fe}$, $\mathrm{N}$ and $\mathrm{P}$ in cherry tomato fruits.

The fertilization of $\mathrm{CO} 3$ reduced the weight. The fertilization $\mathrm{CO} 1$ e CO2 increased AT, Mn and decrease the ratio SS / AT, $\mathrm{K}$ and $\mathrm{Ca}$.

There was no nutritional deficiency of tomatoes in any of the proportions of organic waste studied

The treatment with CO5 can be considered the best among the others, not causing nutritional deficiency in the fruits of cherry tomatoes, in addition to promoting a final destination in food waste.

Acknowledgment: This work was carried out with the support of the Coordination for the Improvement of Higher Education Personnel - Brazil (CAPES) - Financing Code 001.

Conflicts of Interest: "The authors declare no conflict of interest." "The funders had no role in the design of the study; in the collection, analyses, or interpretation of data; in the writing of the manuscript, or in the decision to publish the results".

\section{REFERENCES}

1. FAO. Food and Agriculture Organization of the United Nations. FAOSTAT 2017. Available in: $<$ http://www.fao.org/faostat/en/\#data/QC>. Accessed in: 2019 jan 13.

2. IBGE - Instituto Brasileiro de Geografia e Estatística. SIDRA. Produção Agrícola Municipal. Tabela 5457. 2017. Available in: <https://sidra.ibge.gov.br/tabela/5457\#resultado>. Accessed in: 2019 jan 25.

3. Alvarenga MAR (ed). Tomate: produção em campo, em casa-de-vegetação e em hidroponia. UFLA, Lavras/Brasil, 2013. $455 \mathrm{pp}$.

4. Lima CJGS, Oliveira FA, Medeiros JF, Oliveira MKT, Galvão DC. Avaliação de diferentes bandejas e substratos orgânicos na produção de mudas de tomate cereja. Rev Ciênc Agron. 2009;40(1):123-8.

5. Silva AC, Costa CA, Sampaio RA, Martins ER. Avaliação de linhagens de tomate cereja tolerantes ao calor sob sistema orgânico de produção. Rev Caatinga. 2011;24(3):33-40.

6. Luz JMQ, Shinzato AV, Silva MAD. Comparação dos sistemas de produção de tomate convencional e orgânico em cultivo protegido. Biosci J. 2007;23(2):7-15.

7. Vieira DAP, Cardoso KCR, Dourado KKF, Caliari M, Soares Júnior MS. Qualidade física e química de minitomates Sweet Grape produzidos em cultivo orgânico e convencional. Rev Verde Agroecologia Desenvolv Sustent. 2014;9(3):100-8.

8. Nassur RCMR, Boas EVBV, Botrel N, Resende FV. Doses de composto orgânico e sua influência na manutenção da qualidade de tomates. Revista de Ciências Agrárias/Amazon J. Agric. Environ. 2016;58(4):342-8. http://dx.doi.org/10.4322/rca.1865

9. Lim SL, Lee LH, Wu TY. Sustainability of using composting and vermicomposting technologies for organic solid waste biotransformation: recent overview, greenhouse gases emissions and economic analysis. J Clean Prod. 2016;111:262-78. https://doi.org/10.1016/j.jclepro.2015.08.083

10. Scoton EJ, Battistelle RAG, Bezerra BS, Akutsu J. A sewage sludge co-composting process using respirometric monitoring method in hermetic rotary reactor. J Clean Prod. 2016;121:16975.https://doi.org/10.1016/j.jclepro.2015.04.081

11. Vázquez MA, Varga DL, Plana R, Soto M. Integrating liquid fraction of pig manure in the composting process for nutrient recovery and water re-use. J Clean Prod. 2005; 104: 80-9. https://doi.org/10.1016/j.jclepro.2015.05.016

12. EMBRAPA - Empresa Brasileira de Pesquisa Agropecuaria. Manual de análises químicas de solo, plantas e fertilizantes. EMBRAPA Informação Tecnólogica, Brasília/DF, 2009, BRA. 627p. 
13. Association of Official Analytical Chemistry - AOAC. Official methods of analysis of the Association of Official Analytical Chemistry. 17th ed. Washington: AOAC. 2002, 1115p.

14. Instituto Adolfo Lutz. Normas analíticas, métodos químicos e físicos para análise de alimentos. 3. ed. São Paulo: Instituto Adolfo Lutz.1985, 1, pp. 533.

15. Nagata M, Yamashita I. Simple method for simultaneous determination of chlorophyll and carotenoids in tomato fruit. Nippon Shokuhin Kogyo Gakkaish. 1992;39(10):925-8.

16. Yemm EW, Willis AJ. The estimation of carbohydrates in plant extracts by anthrone. Biochem J. 1954;57:50814.https://doi:10.1042 / bj0570508

17. Tedesco MJ, Gianello C, Bissani CA, Bohnen H, Volkweiss, SJ. Análise de solo, plantas e outros materiais. UFRGS, Porto Alegre. 1995, pp. 173.

18. Silva FAS, Azevedo CAV. Principal components analysis in the software Assistat Statistical Assistance. In: World Congress on Computers in Agriculture, 7, 2009, Reno. Proceedings. St. Joseph: ASABE. 2009, pp. 1-5.

19. Nascimento AR, Soares Junior MS, Caliari M, Fernandes PM, Rodrigues JPM, Carvalho WT. Qualidade de tomates de mesa cultivados em sistema orgânico e convencional no estado de Goiás. Hortic Bras. 2013;31(4):628-35.

20. Pascale S, Maggio A, Orsini F, Barbieri G. Cultivar, soil type, nitrogen source and irrigation regime as quality determinants of organically grown tomatoes. Sci Hortic. 2016;199:88-94. https://doi.org/10.1016/j.scienta.2015.12.037

21. Anthon GE, Barrett DM. Pectin methylesterase activity and other factors affecting $\mathrm{pH}$ and titratable acidity in processing tomatoes. Food Chem. 2012; 132 (2): 915-20. https://doi.org/10.1016/j.foodchem.2011.11.066

22. Ferreira SMR, Quadros DA, Karkle ENL, Lima JJ, Tullio LT, Freitas RJS. Qualidade pós-colheita do tomate de mesa convencional e orgânico. Ciênc Tecnol Aliment. 2010;30(4):858-64. http://dx.doi.org/10.1590/S010120612010000400004.

23. Vinha AF, Barreira SV, Costa AS, Alves RC, Oliveira MBP. Organic versus conventional tomatoes: Influence on physicochemical parameters, bioactive compounds and sensorial attributes. Food Chem Toxicol. 2014;67:139-44. https://doi.org/10.1016/j.fct.2014.02.018

24. Antoniadis V. Mineralization of organic-amendment-derived nitrogen in two Mediterranean soils with different organic-matter contents. Commun Soil Sci Plant Anal. 2013;44(19):2788-95. https://doi.org/10.1080/00103624.2013.815199

25. Preczenhak AP, Resende JT, Chagas RR, Silva PR.; Schwarz K, Morales RG. Caracterização agronômica de genótipos de minitomate. Hortic Bras. 2014;32(3):348-56. http://dx.doi.org/10.1590/S0102-053620140003000018

26. Guilherme DO, Pinho L, Cavalcanti TFM, Costa CA, Almeida AC. Análise sensorial e físico-química de frutos tomate cereja orgânicos. Rev Caatinga. 2014;27(1):181-6.

27. Beckles DM. Factors affecting the postharvest soluble solids and sugar content of tomato (Solanum lycopersicum L.) fruit. Postharvest Biol Technol. 2012;63(1):129-40. https://doi.org/10.1016/j.postharvbio.2011.05.016

28. Teka TA. Analysis of the effect of maturity stage on the postharvest biochemical quality characteristics of tomato (Lycopersicon esculentum Mill.) fruit. Int J Appl Pharm Sci Res. 2013;3(5):180-6.

29. Hallmann, E. The influence of organic and conventional cultivation systems on the nutritional value and content of bioactive compounds in selected tomato types. J Sci Food Agric. 2012;92(14):2840-8. http://dx.doi: 10.1002/jsfa.5617.

30. Borguini RG, Bastos DHM, Moita-Neto JM, Capasso FS, Torres EAFS. Antioxidant potential of tomatoes cultivated in organic and conventional systems. Braz Arch Biol Technol. 2013;56(4):521-9. http://dx.doi.org/10.1590/S151689132013000400001

31. Lacatus V, Botez C, Popescu N, Voican V. Chemical composition of tomato and sweet pepper fruits cultivated on active substrates. In: I International Symposium on Solanacea for Fresh Market 412. Malaga, Spain, 1995; pp: 16875.

32. Aguirre NC, Cabrera FAV, Arango NA. Evaluación del contenido de antioxidantes en introducciones de tomate tipo cereza (Solanum spp.). Acta Agrono. 2012; 61 (3): 230-8.

33. Luo Z, Zhang J, LI J, Yang C, Wang T, Ouyang B, Li H, Giovannoni J, Ye Z. A Stay-green protein SISGR1 regulates lycopene and $\beta$-carotene accumulation by interacting directly with SIPSY1 during ripening processes in tomato. New Phytol. 2013;198(2):442-52. https://doi.org/10.1111/nph.12175

34. Leal FRR, Cecilio Filho AB, Cortez JWM, Barbosa JC. Nitrogen and potassium concentration in the nutrients solution for the production of Tomato. Afr J Agric Res. 2015;10(15):1823-31. http://dx.doi.org/10.5897/AJAR2014.9224

35. Mehmood N, Ayub G, Ullah I, Ahmad N, Noor M, Khan AM, Ahmad S, Saeed A, Farzana. Response of tomato (Lycopersicon esculentum mill.) cultivars to nitrogen levels. Pure Appl Bio. 2012;1(3) 63-7. 
36. Ernani PR, Almeida JA, Santos FC. Potássio. In: Novais RF, Alvarez VH, Barros NF, Fontes RLF, Cantarutti RB, Neves JCL. Fertilidade do solo. SBCS/UFV, Viçosa. 2007; BRA. p. 551-594.

37. Ho LC, Adams P. Nutrient uptake and distribution in relation to crop quality: Hidroponic and transplant production. Acta Hot. 1995: 396: 33-44. http://dx.doi.org/10.17660/ActaHortic.1995.396.3

38. Moreira CA. Biofertilizantes: nutrição e desenvolvimento de tomate orgânico. 110 p. Tese (Doutorado em Agronomia) - Faculdade de Ciências Agronômicas da UNESP, Botucatu, BRA, 2012.

39. Silva TT, Modesta RCD, Penha EM, Matta VM, Cabral LMC. Suco de maracujá orgânico processado por microfiltração. Pesqui agropec bras. 2005; 40 (4): 419-422. http://dx.doi.org/10.1590/S0100-204X2005000400015

40. Pereira Neto, J. T. Manual de compostagem: processo de baixo custo. 2007, Viçosa, UFV81 p.

41. Azevedo, MA. Estudo e avaliação de quatro modos de aeração para sistemas de compostagem em leiras. 1993. 230 f. Dissertação (Mestrado em Saneamento e Meio Ambiente) - Universidade Federal de Minas Gerais, Belo Horizonte. 1993.

CC (i) (5) 2021 by the authors. Submitted for possible open access publication under the terms and conditions of the Creative Commons Attribution (CC BY NC) license (https://creativecommons.org/licenses/by-nc/4.0/). 